\title{
Gaet'ale- a reactivated thermal spring and potential tourist hazard in the Asale salt flats, Danakil Depression, Ethiopia
}

\author{
Sharad Master
}

\begin{abstract}
This paper serves to document a thermal spring, called Gaet'ale, that was reactivated in 2005, during the majorseismo-volcanic crisis in the Danakil Depression of the Afar region of northern Ethiopia. Many dead birds surrounding the spring attest to deadly gas emanations (almost certainly $\mathrm{CO}_{2}$ ) coming from this spring, reminiscent of those from other volcanic lakes, and the Pamukkale springs in Turkey. Gae'tale currently features among the tourist attractions of the Dallol region of the northern Afar, but it may pose a potentially dangerous, and even deadly, hazard for tourists and their guides. Some suggestions are made to help mitigate the risks, and to allow for sustainable geotourism in this environmentally sensitive region. These include ensuring that tour operators in the area are made aware of the hazards, and are communicating these to their tourist clients (who should also be aware of these hazards through websites, tour guidebooks and open-access scientific journals), and avoiding the areas closest to the lake, and periodic testing, with lit flames, for the presence of excess $\mathrm{CO}_{2}$ in the area, with plans for quick and safe evacuation if needed. Guidelines for proper conduct are given for geotourists who are planning to visit the region, to ensure their health and safety in the vicinity of the thermal springs.
\end{abstract}

Keywords: Thermal spring, $\mathrm{CO}_{2}$ emissions, Dead birds, Tourist hazard mitigation measures

\section{Introduction}

The Afar region of northern Ethiopia is one of the most tectonically active regions in the world, and is the site of abundant recent volcanic activity and seismicity (Wright et al. 2006; Darrah et al. 2012; Chernet 2013; Yirgu 2013).

During the post-conference excursion to Afar (Kidane 2013), following the $24^{\text {th }}$ Colloquium of African Geology in Addis Ababa (8-13 January 2013), the thermal springs (or hotsprings) around Dallol (Figs. 1 and 2) were visited by an international group of geoscientists and other researchers. Observations made at Dallol, the Black Water spring (situated at $14^{\circ} 13^{\prime} 18.76^{\prime \prime} \mathrm{N}, 40^{\circ} 17^{\prime} 10.33^{\prime \prime} \mathrm{E}$, Fig. 2), and at a relatively recently-formed spring (Figs. 3, $4,5,6$ ), called Gaet'ale by the local Afar people, (which has not been monitored scientifically since it was formed), were supplemented by information gathered from local people and tourist guides. Many dead birds were observed

Correspondence: sharad.master@wits.ac.za

EGRI, School of Geosciences, University of the Witwatersrand, P. Bag 3, WITS 2050, Johannesburg, South Africa around the Gaet'ale springs and lake (Fig. 7), and locals have observed the birds dying due to gas emanations from the lake. These observations indicate that the Gaet'alespring and lake may pose a dangerous (and even potentially deadly) health hazard for human visitors. Here I describe the spring and lake, and propose measures that may be taken to mitigate the potential health risks.

\section{Regional setting}

The Danakil Depression is located near the triple junction of the Red Sea, Gulf of Aden and the Ethiopian Rift, formed by the rifting away of Arabia from Africa in Oligocene times, at about 24 Ma ago (Kursten 1972; Beyene and Abdelsalam 2005). The floor of the Danakil Depression is located about $120 \mathrm{~m}$ below sea level. The Dallol area is located $80 \mathrm{~km}$ northwest of an active volcanic ridge, which includes the volcano Erta Ale, which has a permanent lava lake (Barberi and Varet 1970, 1975). At Dallol, in the middle of a hot-spring area, there is a mound, called Mount Dallol, which is elevated $60 \mathrm{~m}$ above the surrounding plains which are situated at120 m below sea level. On a satellite image (Fig. 2),
焦 Springer

(c) 2015 Master. Open Access This article is distributed under the terms of the Creative Commons Attribution 4.0 International License (http://creativecommons.org/licenses/by/4.0/), which permits unrestricted use, distribution, and reproduction in any medium, provided you give appropriate credit to the original author(s) and the source, provide a link to the Creative Commons license, and indicate if changes were made. 


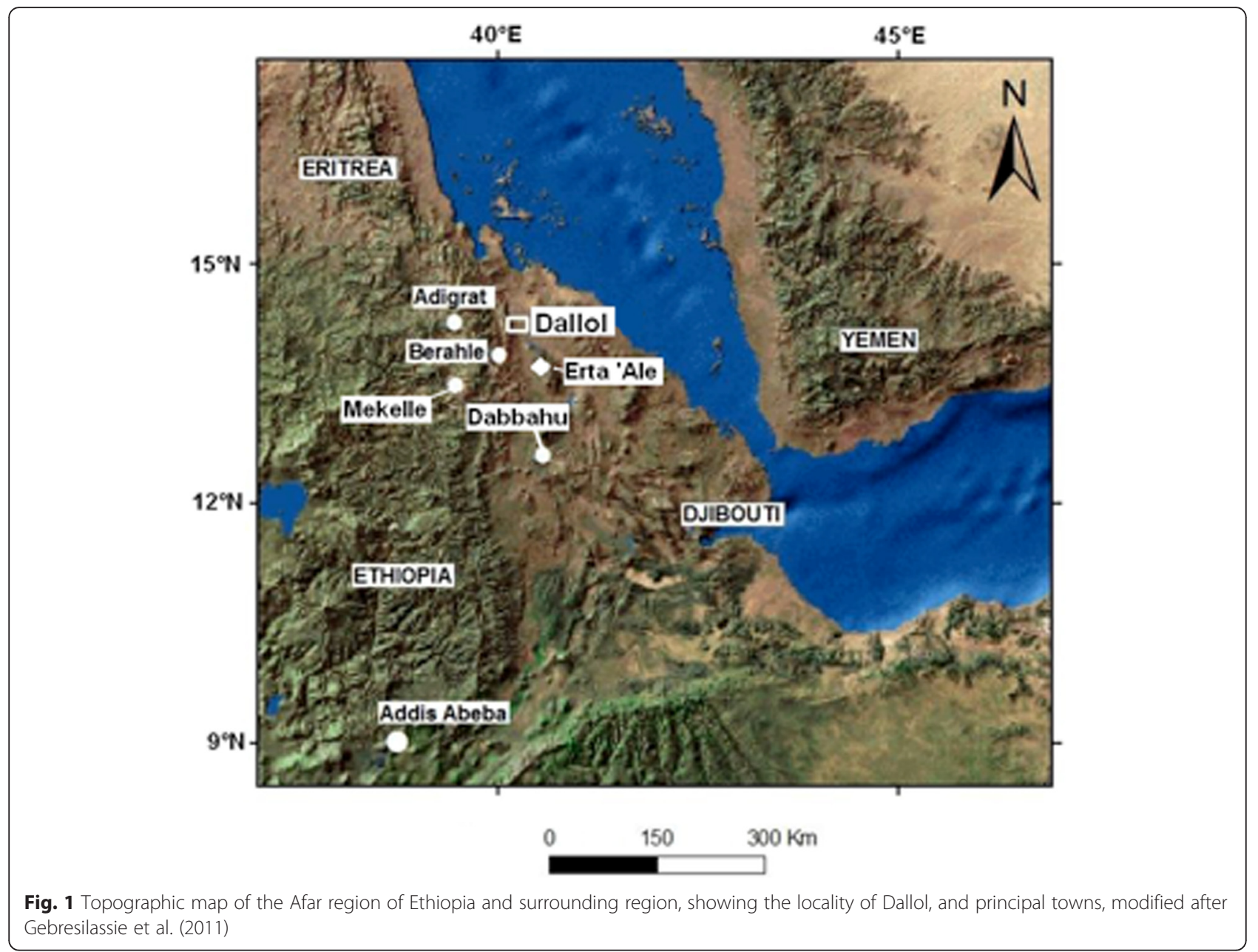

Mount Dallol resembles a volcanic mound with craters, althoughits surface geology is dominated by evaporite rocks and hydrothermal spring deposits, with no volcanics (Holwerda and Hutchinson 1968; Darrah et al. 2012).

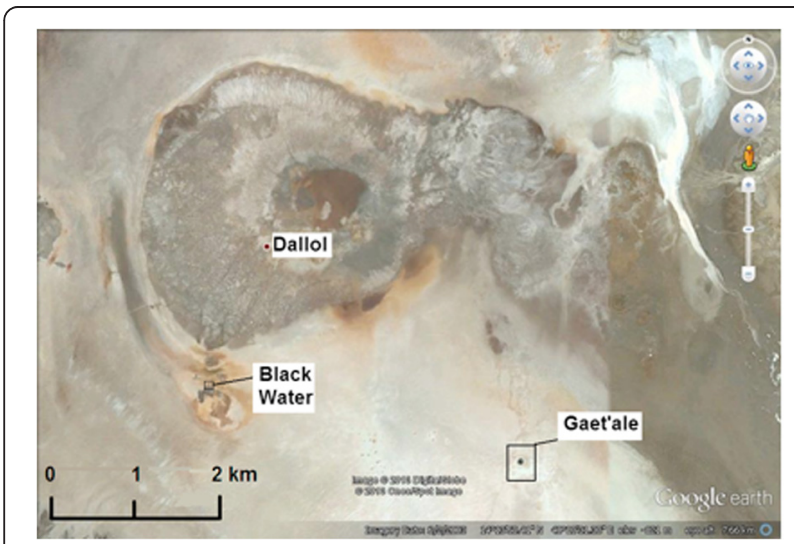

Fig. 2 Satellite image of the region around Dallol hotsprings, showing the locations of the Black Water and Gaet'ale springs. Source: Google Earth
The area surrounding Dallol is occupied by Lake Asale, an ephemeral salt lake, which sits atop a $2-\mathrm{km}$ thick evaporite sequence (Behle et al. 1975), which is dominated by halite and sylvite, together with subordinate layers rich in carnallite and kainite (Holwerda and Hutchinson 1968). The evaporite sequence formed when an arm of the Red Sea was isolated by an uplifted horst

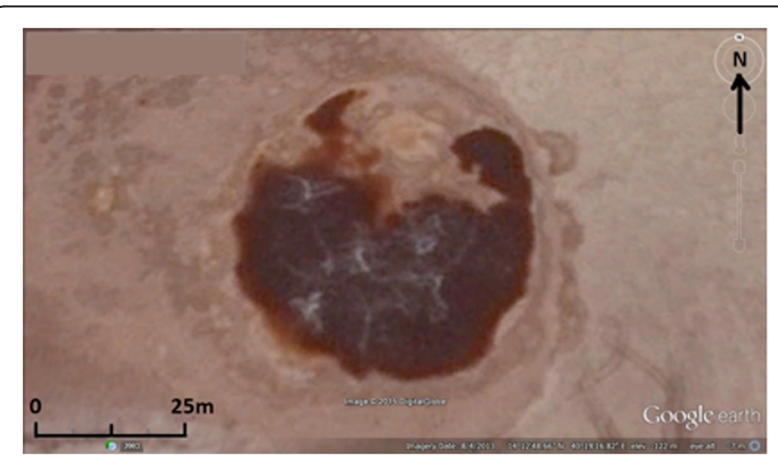

Fig. 3 Detailed Google Earth satellite image of the Gaet'ale hotspring and lake, 8 April 2013. Note the vehicle tracks to the south-east of the lake 


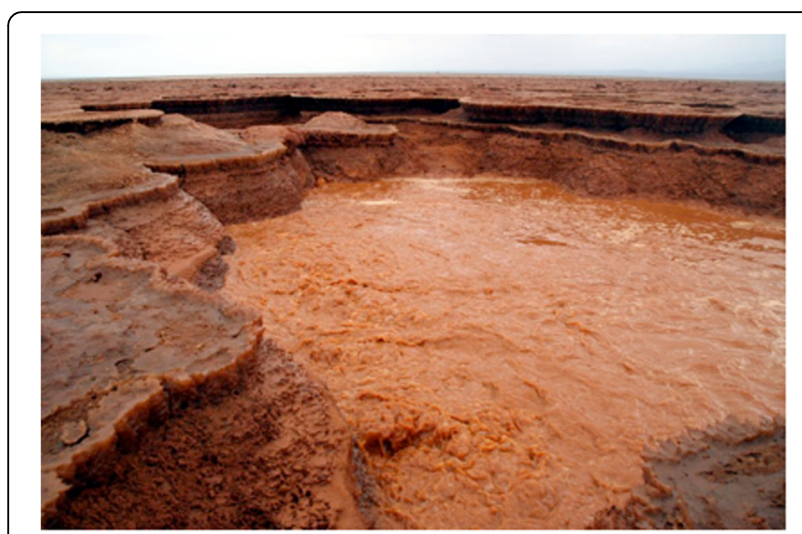

Fig. 4 Gaet'ale spring during a turbulent episode in 2012. Photograph by Gabor Merkl, from Panoramio (2015)

block, causing the sea to evaporate completely (Kursten 1972; Beyene and Abdelsalam 2005). The oldest rocks in the region are deformed Neoproterozoic arc terrains that form the local basement, exposed on the flanks of the rifted southwestern margin of the Ethiopian Rift. This basement is overlain by rocks of the Mesozoic Mekelle Basin, comprising the Jurassic Adigrat sandstones and Antalo limestones, and the Cretaceous Amba Aradom sandstones (Beyth 1972). The Mekelle Basin, in turn is overlain by late Cenozoic (Eocene to Recent) mafic volcanic rocks of the Afar Traps and the so-called "Stratoid Series" (Barberi and Varet 1975), forming the floor of the Danakil Depression, which is overlain by the Danakil evaporites (Bosworth et al. 2005). The ephemeral Lake Asale is found on the surface of the evaporites- it getsrecharged and resurfaced by sheetfloods and groundwater emanating from the Ethiopian highlands. The Dallol springs have evaporitic tufas deposited around them. The Black Water and Gaet'ale springs are found erupting through the evaporites around the Dallol mound. The

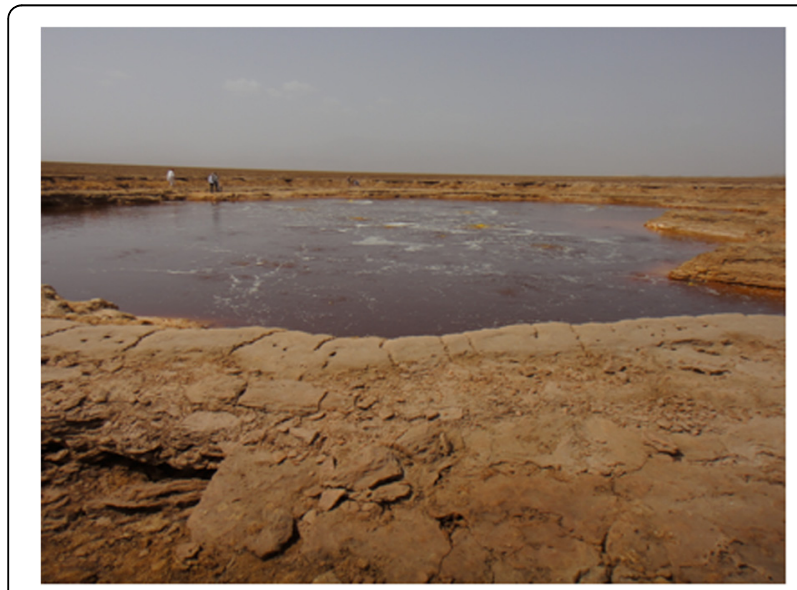

Fig. 5 General view of the Gaet'ale spring, showing small jets of hot yellow water bubbling up in the lake. There is a prominent ledge of salt (halite) in the foreground

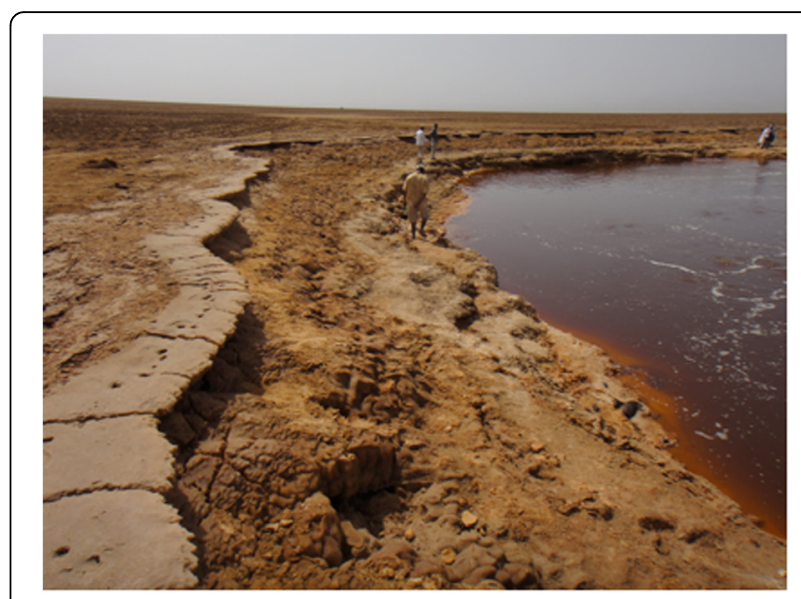

Fig. 6 A view of the descent to the dark brown waters of Gaet'ale lake, showing the terraced evaporite slopes to the lake from the prominent halite ledge. Note the dead birds on the water's edge in the right foreground

spring waters gush up under pressure, and form small fountains or jets which bubble up from the surface of the small lakes that are formed around the springs.

\section{Gaet'ale spring and lake}

The spring of Gaet'ale is situated at $14^{\circ} 12^{\prime} 48.8^{\prime \prime} \mathrm{N}, 40^{\circ}$ 19'16" E, $3.8 \mathrm{~km}$ southeast of the Dallol spring and crater. The spring feeds a roughly circular lake which is about $70 \mathrm{~m}$ in diameter (Fig. 3). It is not known when the lake was originally formed, but freely available high resolution Landsat satellite imagery taken on 6 February 2003 on Google Earth shows that the lake existed then in much the same shape and size as at present. The waters of the lake are yellowish orange to reddish orange in colour, from dissolved iron salts, and do not have any

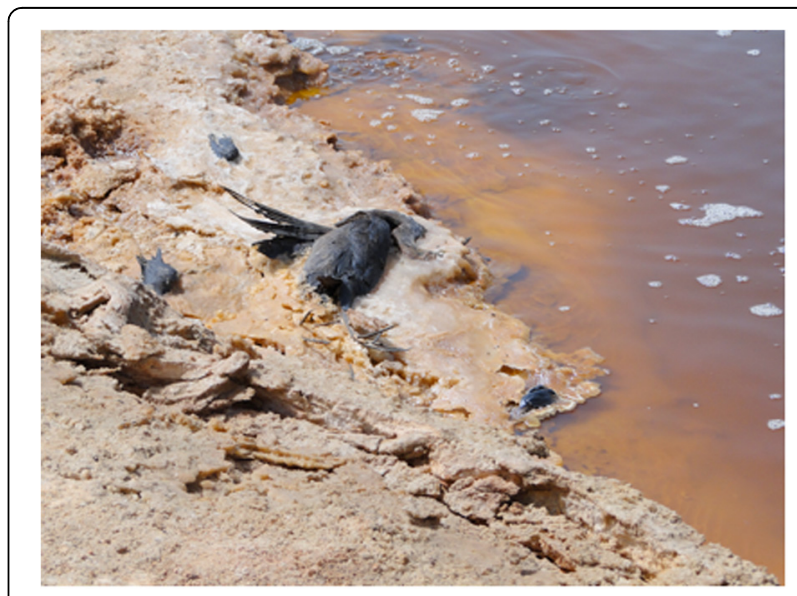

Fig. 7 A close-up view of four dead birds (also seen in Fig. 6), partly enclosed in salt, right on the edge of the Gaet'ale spring lake. Thelargest bird, in the centre, is a black-headed heron (Ardea melanocephala). The other birds cannot be positively identified, but are probably ravens or swifts 
sulphurous odour (Figs. 4, 5, 6). The spring water bubbles up powerfully in several small fountains, and is bright yellow in colour (Fig. 5). The lake level is about $1.5 \mathrm{~m}$ below the level surrounding salt flat of Asale salt lake. About half a metre above the lake level, there is a flat step-like terrace made of light-coloured halite, which is overlain by a metre of slightly darker yellowish-brown sediment consisting of a mixture of salt and mud, overlain by a surficial layer of light-coloured halite about $10 \mathrm{~cm}$ thick, which forms a scalloped ledge jutting out around the perimeter of the lake, with an undercut fringe where the underlying muddy salt has been dissolved away (Fig. 6). The surficial salt is overlain by a thin veneer of dark sediment. Around the margins of the lake, which are raised very slightly above the surrounding flat salt plain, there has been deposited a ring of debris made up of wood and plant material, some of it burnt to charcoal, and mixed in with this were artefacts of recent human origin, such as rubber sandals. Among this debris were the decayed remains of several locusts. According to Yahya our tour guide, the debris washed in by rains coming from the highlands, which produce sheetfloods carrying this material in from near human settlements, such as Afar villages which are found sparsely scattered in this area.

The following information was obtained from touroperators, and residents of Ahmedela, the nearest inhabited village to the Dallol springs. The spring activity started anew following an earthquake in January 2005. At the start, there was a geyser fountaining up to $3 \mathrm{~m}$ high, and it lasted for 3 years. The water was not hot, and not very acid, since people tasted it. "The Black Water is strongly acidic, but this one is not". Our informant Ali Mohamed (pers. comm., 19 January 2013) personally observed birds dying due to gases released from the spring. The birds ate insects that lived in the spring. The birds do not die all the time, but at certain distinct periods (i.e., the mortalities are not continuous).

In 2004, a dyking event, accompanied by a 5.5 magnitude earthquake, took place some $12 \mathrm{~km} \mathrm{SSW}$ of Dallol (Nobile et al. 2012). The earthquake or earthquakes of 2005, which resulted in the formation of the Gaet'ale spring and lake, were part of a major seismo-volcanic crisis which affected the Danakil Depression in the Afar in late 2005, with a major dyking event, accompanied by lots of seismicity (Wright et al. 2006; Ayele et al. 2007; Yirgu 2013). There were 15 earthquakes greater than magnitude 5, a small explosive silicic volcanic eruption, and a $60 \mathrm{~km}$-long dyking event in the Dabbahu area (Fig. 1) some 200 to $250 \mathrm{~km}$ south of Dallol (Ayele et al. 2007, 2009). The volcano-seismic crisis produced stresses which affected the Erta 'Ale volcano (Fig. 1) (Ayele et al. 2007), and it is likely to have affected the Dallol region as well. While earthquake-induced fluid flow has been observed in other areas such as Japan, and has been explained by the dilatancy-fluid diffusion model (Nur 1974), it is more likely that the Gaet'ale spring was produced by seismically-induced reorganization of hydrothermal plumbing connected to a near-surface magma chamber of the nearby Dallol crater (Carniel et al. 2010), which is very active, and has produced a phreatic eruption in 1929, and a recent ash cloud in January 2011 (Chernet 2013). Strong turbulent activity of the Gaetale spring, which had turned the waters into an opaque, muddy orange colour, was recorded in 2012 (Fig. 5).

At least ten dead birds were seen all around the circular spring-fed lake, and all of them were well-preserved, having effectively been pickled by the hypersaline brine of the lake. The largest bird was a black-headed heron (Ardea melanocephala, Ash and Atkins 2009), which was partly covered in salt. The other birds, which were in various states of entombment by the surrounding salt, were black birds, with short white beaks, somewhat resembling the Ethiopian raven (Corvus edithae), but smaller, and other small birds with barred wings which have not been positively identified, but are possibly swifts, which have been recorded around Dallol and the Danakil in general (Thesiger and Meynell 1935; Aerts et al. 2006). Some appeared to have died very recently, being unaffected by salt, while others had been around for a while, and were partly encrusted or buried by salt. A number of dead insects were found, including a $2.5 \mathrm{~cm}$ long glider beetle, a $3 \mathrm{~cm}$ long locust, and twoquite decomposed moths. Arachnids of the order Solifugae (commonly known as "camel spiders") are also known in the Dallol area (Aerts et al. 2006). The insects and arachnids are the main attraction for birds in the springs in the Dallol area. Two dead birds have also been noted around the Black Water spring in January 2011 by Maxwell Matongo, an exploration geologist who was working in the area (Matongo, personal communication, 2 July 2013).

\section{Chemistry and origin of the gaseous emanations from Gaet'ale}

The water temperature at Gaet'ale is not very hot to the touch, unlike the nearby Black Water spring, where the temperature is very hot, as tested by our group, and was measured as $70{ }^{\circ} \mathrm{C}$ (Darrah et al. 2012). The water has agreasy or soapy feeling, but this is not due to oil, as surmised by Gebresilassie et al. (2011), but due to supersaturation in dissolved salts, which precipitate readily on cooling. The bright yellow colour of the spring waters in the Dallol area are due to the ironchlorocomplex ferrochlorate III (Pittwell 1972a, b, 1973). Gebresilassie et al. (2011) reported on the chemistry of these waters, from the spring at UTM location 0640078/ 1572390, (i.e., Gaet'ale) which had pH of 3.50-3.95, Total Organic Carbon (TOC) contents of between 36 and 
409 ppm, Total Dissolved Solutes (TDS) of 96 to 110.4 ppm, $\mathrm{SO}_{4}^{2-}$ contents of 21 to $117 \mathrm{ppm}$, and sulfide contents of 40-960 ppb. The low TOC contents confirm that the greasy feeling of the spring was not due to oil.

It is well known that $\mathrm{CO}_{2}$ is produced copiously from the volcanoes of the Afar, such as Erta'Ale (Tazieff et al. 1972; Le Guern et al. 1979; Gerlach 1980, 1981, 1989; Sawyer et al. 2008) and volcanically-derived $\mathrm{CO}_{2}$ is oneof the major sources of dissolved bicarbonate in Ethiopian Rift spring waters (Gizaw 1996). The hotsprings at Dallol were shown to be enriched in ${ }^{18} \mathrm{O}$ due to isotopic exchange with the volcanic rocks (Gonfiantini et al. 1973). Recently, a detailed isotopic and geochemical study of the spring waters around the Dallol hydrothermal system has revealed the presence of primordial ${ }^{3} \mathrm{He}$ among the gaseous components, revealing the magmatic origin of the gases, including the abundant $\mathrm{CO}_{2}$ (Darrah et al. 2012). The Dallol hydrothermal system has been regarded as the result of interaction and assimilation of salt deposits byintruding mafic magmas, resulting in the formation of iron chloride sublimates which mix with meteoric waters heated by the volcanism, and ultimately precipitate ironrich salts which give the bright colours to the Dallol deposits (Master 2013). The dead birds at Gaet'ale and Black Water were most probably killed by $\mathrm{CO}_{2}$ emanations, such as were observed coming out of the Dallol crater in the first week of January 2011 (Chernet 2013).

\section{$\mathrm{CO}_{2}$ emanations at Gaet'ale as a potential health hazard for tourists}

Volcano and geothermal spring tourism is a growing component of geotourism, and is enjoying an increasing popularity worldwide (Erfurt-Cooper and Cooper 2010). It is becoming more popular in Ethiopia, where the major drawcards are the volcano Erta 'Ale, with its permanent lava lake, and the Dallol springs, with their spectacularly colored waters, mineral salts, and landforms (Edelman and Roscoe 2010). Geotourism has been defined as tourism that enhances or sustains the geographical character of a place and its environment, as well as its culture, aesthetics and heritage, and it also incorporates the idea of sustainable tourism, in which destinations should remain unspoilt for future generations (Lew 2002). In order to make volcanic landscapes sustainable as geotourism destinations, the potential hazards posed by these regions need to be recognized and publicized (Baxter et al. 1986; Hansell and Oppenheimer 2004; Hansell et al. 2006; Heggie 2009). Volcanoes and associated volcanic springs and emanations are a potential human and animal health hazard which has been documented in many places since ancient times (Heggie 2010; Baxter 2005, 2010). A wide range of hazards are found in volcanic areas and include lava flows, tephra and ash falls from volcanic eruptions, associated earthquakes, landslides, mudflows and lahars, and volcanic gas emissions, volcanic laze, and acid rain (Hansell et al. 2006; Heggie 2009).

One of the major hazards in volcanic regions is posed by volcanic gas emanations, which may originate from lava lakes, volcanoes, volcanic lakes, faults and fissures, and from hotsprings (Baxter et al. 1990, 1999; Hansell and Oppenheimer 2004; Hansell et al. 2006; Zuskin et al. 2007; Heggie 2009). The volcanic gases include $\mathrm{CO}_{2}$, $\mathrm{SO}_{2}, \mathrm{HCl}, \mathrm{H}_{2} \mathrm{~S}, \mathrm{HF}, \mathrm{CO}, \mathrm{N}_{2}, \mathrm{H}_{2}, \mathrm{He}, \mathrm{CH}_{4}, \mathrm{Rn}$, together with volatile elements such as $\mathrm{Pb}$ and $\mathrm{Hg}$.

Carbon dioxide $\left(\mathrm{CO}_{2}\right)$ is an abundant volcanic gaswhich is emitted during volcanic eruptions and in geothermal areas, and is particularly insidious and dangerous because it is odorless, and denser than air (Heggie 2009). On the 20th February 1979, a phreatic eruption of the Dieng volcano on Java, Indonesia, caused a $\mathrm{CO}_{2}$ gas emanation which overflowed from the crater and rolled downhill, killing 142 people (Le Guern et al. 1982; Allard et al. 1989). In the volcanic regions of Cameroon, deadly releases of $\mathrm{CO}_{2}$ gas resulted in the deaths of 37 people at Lake Monoum in 1984, and about 1700 people at Lake Nyos in 1986, in addition to numerous other animals such as cattle (Sigurdsson 1987; Sigurdsson et al. 1987; Baxter and Kapila 1989; Baxter et al. 1989; Holloway 2000). The $\mathrm{CO}_{2}$ emanations of lakes Nyos and Manoum resulted from trapped volcanic-derived gas released from sediments at the bottom of deep stratified volcanic lakes, and the release may have been triggered by landslides or some other unknown mechanism (Holloway 2000). Othervolcanic areas that are prone to hazardous gas emissions include the Roman volcanic province (Beaubien et al. 2003; Carapezza et al. 2003), and places where geotourists are especially vulnerable, such as the Furnas volcano, Azores (Baxter et al. 1999; Dibben and Chester 1999), the Hawaii Volcanoes National Park (Stephenson et al. 1991; Heggie and Heggie 2004; Heggie 2005; Heggie et al. 2009), and Mammoth Mountain, a dormant volcano and popularrecreation area in California (Sorey et al. 1998). In the case of Gaet'ale, the $\mathrm{CO}_{2}$ gas is also of volcanic origin, but here it is derived from degassing from a near-surface magma chamber, which has triggeredfumarolic and phreato-magmatic activity in the past (Darrah et al. 2012; Chernet 2013).

Comparisons may be drawn between Gaet'ale, which has been demonstrated to be deadly to birds, and other deadly springs where volcanically-derived $\mathrm{CO}_{2}$ emanations have been fatal to animals. Weed (1889) and Jaggar 1899) (cited by Stupfel and Le Guern 1989) described how $\mathrm{CO}_{2}$ emanating from a volcanic spring in the Yellowstone National Park, flowed into a hollow (since it is heavier than air), where it acted as a death trap for several bears who died after inhaling the deadly gas. Another analogy exists between the Gaet'ale springs and the $\mathrm{CO}_{2}$-rich springs at Pamukkale, Turkey (Altunel and 
Hancock 1993). The Pamukkale springs are situated next to the ancient Phrygian town of Hierapolis, which wasfamed for its thermal springs, which were described by the classical geographer Strabo (c. 65 BCE- c. $24 \mathrm{CE}$ ). In April2013, an Italian archaeological team led by Francesco d'Andria announced the discovery, in the town of Heirapolis, of the Ploutonion, a temple dedicated to Pluto, Greek god of the underworld, and regarded in ancient times as the gates of Hades (D'Andria 2013; Pfanz et al. 2014). Strabo (1924, Book XIII, Chapter 4, Section 14), describing the Ploutonion, reported that "this space is full of a vapor so misty and dense that one can scarcely see the ground. Any animal that passes inside meets instant death. I threw in sparrows and they immediately breathed their last and fell." D'Andria reported that he could see the cave's lethal properties during the excavation. He stated that "several birds died as they tried to get close to the warm opening, instantly killed by the carbon dioxide fumes" (Walsh 2013).

Although they are situated in an inhospitably hot, unrelentingly bleak, hostile and barren salt plain, devoid of any shade or vegetation, the yellow bubbling springs of Gae'tale act as a magnet for tour operators who bring increasingly more geotourists to the region around the Dallol hot springs and the active volcanoes of Danakil (Edelman and Roscoe 2010; Weber 2015). On the website Panoramio (2015), around 100 photographs of the Dallol hot springs have been posted by dozens of visitors, and five different people have posted photographs of the spring and lake at Gaet'ale, as of $29^{\text {th }}$ May 2015. This is evidence of the growing popularity of Gaet'ale as a tourist destination in the Dallol region. Many visitors have also been to Black Water spring. A new road under construction linking Mekelle with the Dallol potash mining region is certain to increase the number of tourists to this area. The episodic and intermittent nature of the $\mathrm{CO}_{2}$ eruptions that have caused mass fatalities of birds around the Gae'tale and Black Water springs are of unknown intensity and duration, and they may also pose a threat to the health and wellbeing of human visitors (tourists and their guides) who come to visit this lake (see below). Tour operators and visitors must be made aware of the hazards associated with the deadly springs of Gaet'ale. Precautions must be taken to speedily and safely evacuate the immediate vicinity of the spring and associated lake, where heavy $\mathrm{CO}_{2}$ may accumulate, should the need arise.

It must be borne in mind that $\mathrm{CO}_{2}$ is colourless and has no smell, and its presence is not easily detected.Because it is heavier than air, it tends to accumulate in hollows and depressions in volcanic areas (Allard et al. 1989; Stupfel and Le Guern 1989; Baxter et al. 1989, 1990, 1999; Baxter 2010). The effects of increasing $\mathrm{CO}_{2}$ concentrations in the air range from a shortage of breath, to dizziness, loss of consciousness and death (Ikeda et al. 1989; Hathaway et al. 2004; Hansell andOppenheimer 2004; Hansell et al. 2006; Cantrell and Young 2009) (Table 1). In some instances, excess $\mathrm{CO}_{2}$ inhalation can lead to toxic sensorineural dysosmia resulting in olfactory distortions (parosmia) and hallucinations (phantosmia), and people have reported smelling "rotten gas" $\left(\mathrm{H}_{2} \mathrm{~S}\right)$, and other smells, as well as narcoticeffects (Seevers 1944; Feldman et al. 1986). Acidic volcanic gas (volcanic laze) can be distinguished from carbon dioxide as it causes severe inflammation of the airways and pulmonary oedema (Heggie et al. 2009), while inhalationof carbon monoxide and nitrous oxides producescarboxyhaemoglobinaemia and methaemoglobinaemia,respectively (Baxter et al. 1989; Hansell and Oppenheimer 2004). These two conditions arise when $\mathrm{CO}$ and $\mathrm{CH}_{4}$ respectively combine with haemoglobin in the blood, and having a greater affinity for haemoglobin than does oxygen, they effectively cause the body to be starved of oxygen, with fatal consequences (Manning et al. 1981; Baxter et al. 1989).

\section{Sustainable geotourism and health risk mitigation at Gaet'ale}

In Ethiopia, the volcanic regions of Erta 'Ale, Dallol and Gaet'ale are not (as yet) part of a national park, so it is difficult to enforce any kind of rules and regulations with regard to visits to potentially dangerous places. These regions are very remote, and only accessible with rugged specially equipped vehicles, and most visits are arranged, organized and carried out by adventure tourism companies based in the Ethiopian cities of Addis Ababa and

Table 1 The effects of increasing $\mathrm{CO}_{2}$ concentrations in the air on human health (after Ikeda et al. 1989; Hathaway et al. 2004; Hansell and Oppenheimer 2004; Hansell et al. 2006; Cantrell and Young 2009)

\begin{tabular}{ll}
\hline$\% \mathrm{CO}_{2}$ in air & Physiological effects on humans \\
\hline 5 & perceptible increase in respiration \\
6 to 10 & shortness of breath, headaches, dizziness, sweating, general restlessness, visual disturbances, tremors \\
10 to 15 & impaired coordination and abrupt muscle contractions, tachycardia \\
$20-30$ & loss of consciousness and convulsions \\
$>30$ & can result in death in $1-10$ min \\
\hline
\end{tabular}


Mekelle (and a few from Europe). Tour operators cannotbe relied upon to provide information that may potentially turn tourists away, and tourists themselves, even in well regulated national parks such as in Hawaii, not infrequently disobey rules and specific instructions, leading to injuries or death (Heggie and Heggie 2004; Heggie 2005). Because of the remoteness of these features, and the lack of oversight by regulatory authorities, the commonly visited geographic features in the Danakil Depression, such as the volcanoes, hotsprings and salt formations, do not have any signs or warnings. One of the major drawcards of the Danakil region is the wild and "unspoilt" nature of the natural environment. In this area any kind of signage or artificial barriers to access will result in despoiling and degrading the aesthetic experience of pristine wilderness, which is one of the main attractions for eco- and geotourists to the area in the first place.

Perhaps the best way of making people aware of the potential dangers of these volcanic springs is throughtourist websites, guidebooks and in open-access scientific journals, which are easily accessible through web-based searches. The majority of adventure tourists to remote places like the Danakil Depression are likely to have done research online and in guidebooks, before embarking on these (usually costly) geotourism adventures.

Periodic testing of the air by checking whether a flame burns (e.g., Stupfel and Le Guern 1989), may be an easy way of detecting the presence of excess $\mathrm{CO}_{2}$ near the Gaet'ale springs. However, this must be done in an environmentally sensitive way (e.g., use must be made of cigarette lighters, rather than matches, which tend to be thrown away, and will end up accumulating as rubbish around an extremely fragile site, where nothing decays). Cigarette lighters themselves, like all other waste, must be carried away and disposed of properly, and no trace of human artefacts should be left at this site, as in all other sites in the region of the Dallol springs and Asale salt lake, in order to preserve the pristine nature of the environment and make it sustainable for tourism. People should be warned not to walk on the lower terrace immediately surrounding the lake, where $\mathrm{CO}_{2}$ may accumulate, and where all of the dead birds were found, but to observe it from the upper terrace, where the threat of carbon dioxide poisoning is much reduced. The flat and exposed nature of the surrounding plains would favor the dilution and dispersal of $\mathrm{CO}_{2}$ eruptions from these springs, unlike the situation in hilly volcanic regions where $\mathrm{CO}_{2}$ is funneled down topographic gradients.

The Black Water spring is more open, and does not have a stepped hollow depression like Gaet'ale, and hence there is much less of a threat of toxic $\mathrm{CO}_{2}$ accumulation there, even though deadly vapours are occasionally given off, as attested by the observations of dead birds there in the past. Nevertheless, the Black Water spring is still quite dangerous for anybody who goes near its edge, because of the risk of sinking into hot mud, or of falling into the spring-fed lake itself. Prof. Jacques Varet recounted (pers. comm., January 2013) that in the early 1970's, he had approached the edge of the Black Water spring to sample it, and he collapsed into hot saturated mush, which behaved very much like quicksand, and only saved himself by falling backwards with his arms outspread, in order to distribute his weight more widely. He suffered serious burns on his lower legs, from being scalded by the extremely hot spring waters.

The Danakil Depression and its tourist attractions are not outside of government control and interest. In 2012, a number of foreign tourists were abducted from Dallol by Eritrean-based rebels and taken across the border toEritrea, where they were killed. Subsequently, the Ethiopian army made reprisal raids to eliminate the rebels, and haveposted armed guards to accompany groups of tourists visiting the sites of Erta 'Ale and Dallol. This was the case during the January 2013 excursion to the Afarand Danakil Depression as part of the $34^{\text {th }}$ Colloquium of African Geology (Kidane 2013). There is thus a potential for intervention by the Ethiopian Ministry of Tourism toliaise with tour operators in the area, to distribute pamphlets and warnings about the potential dangers of the active volcanoes and $\mathrm{CO}_{2}$-emanating volcanic hotsprings in the region.

Tourists contemplating or planning visits to the Danakil Depression and its volcanic geotourist destinations, especially the thermal springs, are advised to abide by the following guidelines for their own health and safety, to ensure that they are able to enjoy the experience of travel to this unique part of the earth, without undue exposure to potentially harmful and even deadly risks and hazards:-

1. Never go near the edge of any of the hotsprings, such as Gae'tale, Black Water, or Dallol springs. The surrounding salt may be brine-saturated and very weak, and may not support the weight of a person.

2. Do not try to sample the spring waters- since falling in could expose you to extreme scalding, in hot acidic waters (pH of Gae'tale is around 3.5 to 4, Gebresilassie et al. 2011).

3. At Gae'tale, do not descend to the lower terraces immediately surrounding the spring. This is where $\mathrm{CO}_{2}$ tends to accumulate, and it has killed many birds, and may potentially be fatal to humans.

The deadly springs of Gaet'ale deepen the fascination of this region, and their potential for dangerous $\mathrm{CO}_{2}$ gas eruptions would add a touch of irresistible attraction for the particular breed of adventure tourists who are drawnto such areas. These springs may be safely visited if precautions are taken, and people are prevented (or 
dissuaded, by easily accessible information) from climbing down to the water's edge, where the highest risks of $\mathrm{CO}_{2}$ accumulation and poisoning are present.

\section{Competing interests}

The author declares that he has no competing interests.

\section{Acknowledgements}

I am grateful to members of the multidisciplinary international group of researchers that visited the Gaet'ale spring on 19 January 2013, for discussions, especially Tesfaye Kidane (excursion leader), Kurt Klima, Monica Klima, Jacques Varet and Frances Williams. I thank Tamiru Abiye for discussion concerning $\mathrm{CO}_{2}$ and hydrology in the Ethiopian Rift system. I also thank our guides Yahya of Ethio-Der Expeditions, and Ali Mohamed of Ahmedela village, for their input and information. Finally, I am indebted to Maxwell Matongo for the information concerning dead birds at Black Water spring. The School of Geosciences, University of the Witwatersrand, provided funding for this research.

\section{Received: 4 June 2015 Accepted: 18 December 2015}

\section{Published online: 05 January 2016}

\section{References}

Aerts R, Moeyersons J, November E, Nyssen J, Taha N, Aynekulu E, Haile M,Deckers, J. Excursion Guide to the Danakil. HighLAND 2006 Conference, 23-24 September 2006, Mekelle, Ethiopia, 2006. Katholieke Universiteit Leuven, Belgium, 22. https://ivias.kuleuven.be/bitstream/123456789/223188/1/aerts.

Allard P, Dajlevic D, Delarue C. Origin of carbon dioxide emanation from the 1979 Dieng eruption, Indonesia: Implications for the origin of the 1986 Nyos catastrophe. J Volcanol Geotherm Res. 1989;39:195-206.

Altunel E, Hancock PL. Morphology and structural setting of Quaternary travertines of Pamukkale, Turkey. Geol J. 1993;28:335-46.

Ash J, Atkins J. Birds of Ethiopia and Eritrea: An atlas of distribution. London: Christopher Helm; 2009

Ayele A, Jacques E, Kassim M, Kidane T, Omar A, Tait S, et al. The volcano-seismic crisis in Afar, Ethiopia, starting in September 2005. Earth Planet Sci Lett. 2007; 255(1-2):177-87.

Ayele A, Keir D, Ebinger C, Wright TJ, Stuart GW, Buck WR, et al. September 2005 mega-dike emplacement in the Manda-Harraro nascent oceanic rift (Afar depression). Geophys Res Lett. 2009;36:L20306. doi:10.1029/2009GL039605.

Barberi F, Varet J. The Erta Ale volcanic range (Danakil Depression, Northern Afar, Ethiopia). Bull Volcanol. 1970;34(4):848-917.

Barberi F, Varet J. Recent volcanic units of Afar and their structural significance. In: Pilger A, Rosler A, editors. Afar Depression of Ethiopia, Proceedings of an international symposium on the Afar Region and Rift Related Problems, Bad Bergzabern, FRG, 1974, vol. 1. Stuttgart, Germany: E. Schweitzerbart'sche Verlagbuchhandlung; 1975. p. 174-8.

Baxter PJ. Human impacts of volcanoes. In: Marti J, Ernst GGJ, editors. Volcanoesand the environment. New York: Cambridge University Press; 2005. p. 273-303.

Baxter PJ. Volcanoes. In: Koenig KL, Schultz CH, editors. Koenig and Schultz's disaster medicine: comprehensive principles and practices. Cambridge, UK: Cambridge University Press; 2010.

Baxter PJ, Bernstein RS, Buist AS. Preventive health measures in volcanic eruptions. Am J Public Health. 1986;76(suppl):84-90.

Baxter PJ, Baubrun J-C, Coutinho R. Health hazards and disaster potential of ground gas emissions at Furnas volcano, Sao Miguel, Azores. J Volcanol Geotherm Res. 1999;92:95-106.

Baxter PJ, Kapila M. Acute health impact of the gas release at Lake Nyos, Cameroon, 1986. J Volcanol Geotherm Res. 1989:39:265-75.

Baxter PJ, Kapila M, Mfonfu D. Lake Nyos disaster, Cameroon, 1986: the medicaleffects of large scale emission of carbon dioxide? Br Med J. 1989;298: 1437-41.

Baxter PJ, Tedesco D, Miele G, Baubron JC, Cliff K. Health hazards of volcanic gases. Lancet. 1990;336:176

Beaubien SE, Ciotoli G, Lombardi S. Carbon dioxide and radon gas hazard in the Alban Hills area (central Italy). J Volcanol Geotherm Res. 2003;123:63-80.

Behle A, Makris J, Baier B, Delibasis N. Salt thickness near Dallol (Ethiopia) from seismic reflection measurement and gravity data. In: Pilger A, Rösler A, editors. Afar depression of Ethiopia, Proceedings of an International Symposium on the Afar Region and Related Rift Problems, Held in Bad
Bergzabern, FRG, 1974. Stuttgart: E. Schweizerbart'sche Verlagbuchhandlung; 1975. p. 379-90.

Beyene A, Abdelsalam MG. Tectonics of the Afar Depression- a review and synthesis. J Afr Earth Sci. 2005:41:41-59.

Beyth M. Paleozoic-Mesozoic sedimentary basin of Makalle outlier. Am Assoc Pet Geol Bull. 1972:56:2426-39.

Bosworth W, Huchon P, McClay K. The red sea and gulf of aden basins. J Afr Earth Sci. 2005:43:334-78

Cantrell L, Young M. Fatal fall into a volcanic fumarole. Wilderness Environ Med. 2009;20:77-9.

Carapezza ML, Badalameni B, Cavarra L, Scalzo A. Gas hazard assessment in adensely inhabited area of Colli Albani volcano (Cava dei Selci, Roma). J Volcanol Geotherm Res. 2003:123:81-94.

Carniel $\mathrm{R}$, Jolis EM, Jones J. A geophysical multi-parametric analysis of hydrothermal activity at Dallol, Ethiopia. J Afr Earth Sci. 2010;58:812-9.

Chernet T. Dallol volcano and Danakil Depression: earth resources and geohazards. In: Asrat, A. (Compiler), Abstracts, 24th Colloquium of African Geology (CAG24), 40 years of GSAf (1973-2013): Earth Science Solutions to African Development Challenges, 8-14 January, 2013. Addis Ababa, Ethiopia: Millenium Hall; 2013

D'Andria F. II Ploutonion a hierapolis di Frigia. Istanbuler Mitteilungen. 2013:63. $157-217$

Darrah TH, Tedesco D, Tassi F, Vaselli O, Cuoco, E., Poreda RJ (2012). Gas chemistry of the Dallol region of the Danakil Depression in the Afar region of the northernmost East African Rift. Chemical Geology, http://dx.doi.org/10 1016/j.chemgeo.2012.10.036

Dibben C, Chester DK. Human vulnerability in volcanic environments: the case of Furnas, Sao Miguel, Azores. J Volcanol Geotherm Res. 1999;92: 133-50.

Edelman J, Roscoe R. Volcano tourism in Ethiopia and the Danakil rift zone. In: Erfurt-Cooper P, Cooper M, editors. Volcano and geothermal geotourism, sustainable geo-resources for leisure and recreation. Abingdon, Oxon, UK, and New York, NY, USA: Earthscan, Taylor and Francis; 2010.

Erfurt-Cooper P, Cooper M, editors. Volcano and geothermal geotourism, sustainable geo-resources for leisure and recreation. Abingdon, Oxon, UK and New York, NY, USA: Earthscan, Taylor and Francis; 2010.

Feldman JL, Wright HN, Leopold DA. The initial evaluation of dysosmia. Am J Otolaryngol. 1986:4:431-44

Gebresilassie S, Tsegab H, Kabeto K, Gebreyohannes T, Sewale A, Amare K, et al. Preliminary study on geology, mineral potential and characteristics of hot springs from Dallol area, Afar rift, northeastern Ethiopia: implications for natural resource exploration. Momona Ethiop J Sci. 2011;3(2):17-30.

Gerlach TM. Investigation of volcanic gas analyses and magma outgassing from Erta 'Ale lava Lake, Afar, Ethiopia. J Volcanol Geotherm Res. 1980;7:415-41.

Gerlach TM. Restoration of new volcanic gas analyses from basalts of the Afar Region: Further evidence of $\mathrm{CO}_{2}$ - degassing trends. J Volcanol Geotherm Res. 1981;10:83-91.

Gerlach TM. Degassing of carbon dioxide from basaltic magma at spreading centers: I. Afar transitional basalts. J Volcanol Geotherm Res. 1989:39:211-9.

Gizaw B. The origin of high bicarbonate and fluoride concentrations in waters of the Main Ethiopian Rift Valley, East African Rift system. J Afr Earth Sci. 1996: 22(4):391-402.

Gonfiantini RS, Ferrara G, Panichi C. Isotopic composition of waters in the Danakil Depression, Ethiopia. Earth and Planetary Sci. 1973;18:13-21.

Hansell A, Oppenheimer C. Health hazard from volcanic gases: a systematic literature review. Arch Environ Health. 2004;59:628-39.

Hansell AL, Horwell CJ, Oppenheimer C. The health hazards of volcanoes and geothermal areas. Occup Environ Med. 2006;63:149-56.

Hathaway GL, Proctor NH, Hughes JP, Fischman ML. Proctor and Hughes' chemical hazards of the workplace. 5th ed. New York: John Wiley \& Sons: 2004. p. 800

Heggie TW. Reported fatal and non-fatal incidents involving tourists in Hawail volcanoes national park, 1992-2002. Travel Med Infect Dis. 2005;3:123-31.

Heggie TW. Geotourism and volcanoes: health hazards facing tourists at volcanic and geothermal destinations. Travel Med Infect Dis. 2009;2009(7):257-61. Heggie TW. Volcanoes and travel medicine. Travel Med Infect Dis. 2010;8:199-200. Heggie TW, Heggie TM. View lava safely: an epidemiology of hiker injury and illness in Hawaii volcanoes national park. Wilderness Environ Med. 2004:15(2):77-81.

Heggie TW, Heggie TM, Heggie TJ. Death by volcanic Laze. Wilderness Environ Med. 2009;20(1):101-3.

Holloway M. The killing lakes. Sci Am. 2000;283:92-9. 
Holwerda UG, Hutchinson RW. Potash-bearing evaporites in the Danakil Region, Ethiopia. Econ Geol. 1968;63(2):124-50.

Ikeda N, Takahashi H, Umetasu K, Suzuki T. The course of respiration and circulation in death by carbon dioxide poisoning. Forensic J Inter. 1989; 41:93-9.

Jaggar TA. Death Gulch, a natural bear-trap. Popular Science Monthly. Appletone, New York, 54, February 1899, 1-7.

Kidane T. Afar rift tectonics, Erta'ale active volcano and Dallol. Post-Conference Excursion 4 (15-22 January 2013), $24^{\text {th }}$ Colloquium of African Geology, the $14^{\text {th }}$ Congress and $40^{\text {th }}$ anniversary of the Geological Society of Africa, 08-14 January 2013, Addis Ababa, Ethiopia, 2013.

Kursten M. Tektonik, Salz und Vulkanismus in der Danakil-Senke Athiopiens. Geologische Jahrbuch. 1972;90:397-414.

Le Guern F, Carbonnelle J, Tazieff H. Erta 'Ale Lava Lake: Heat and mass transfer to the atmosphere. J Volcanol Geotherm Res. 1979;6:27-48.

Le Guern F, Tazieff H, Faivre Pierret RX. An example of health hazard: people killed by gas during a phreatic eruption: Dieng Plateau (Java), Indonesia, February $20^{\text {th }} 1979$. Bull Volcanol. 1982;45(2):153-6.

Lew AA. Geotourism and what geographers do. Tour Geogr. 2002;4:347-8.

Manning TJ, Ziminski K, Hyman A, Figueroa G, Lukash L. Methane deaths? Was it the cause? Am J Forensic Med Pathol. 1981;2:333-6.

Master S. The unique hydrothermal spring deposits at Dallol (Danakil Depression, Afar, Ethiopia)- products of the interaction between mafic magma and marine evaporites. Johannesburg, South Africa: Turbine Hall; 2013. Abstract, Geocongress 2013, Biennial Congress of the Geological Society of South Africa, 3-5 July 2013.

Nobile A, Pagli C, Keir D, Wright TJ, Ayele A, Ruch J, et al. Dike-fault interaction during the 2004 Dallol intrusion at the northern edge of the Erta Ale Ridge (Afar, Ethiopia). Geophys Res Lett. 2012;39(L19305):2012. doi:10.1029/ $2012 \mathrm{GL} 053152$.

Nur A. Matsushiro, Japan, earthquake swarm: confirmation of the dilatancy-fluid diffusion model. Geology. 1974;2:217-21.

Panoramio (2015). Panoramio- Photos of the World. http://www.Panoramio.com. Accessed on 23 December 2015.

Pfanz H, Yüce G, D'Andria F, D'Alessandro W, Pfanz B, Manetas Y, et al. the ancient gates to hell and their relevance to Geogenic $\mathrm{CO}_{2}$. In: Wexler $P$, editor. History of toxicology and environmental health. Toxicology in Antiquity, vol. 1. Waltham, MA, USA: Academic; 2014.

Pittwell LR. Some coordination effects in natural waters of Ethiopia. J Hydrol. 1972a; 17:225-8

Pittwell LR. A study of some Ethiopian and other natural waters. In: The role of hydrology and hydrometeorology in the economic development of Africa, vol. 2. Geneva, Switzerland: World Meteorological Organization; 1972b. p. 244-50.

Pittwell LR. Some coordination effects in orebody formation. Chem Geol. 1973; 12(1):39-49.

Sawyer GM, Oppenheimer C, Tsanev VI, Yirgu G. Magmatic degassing at Erta 'Ale volcano, Ethiopia. J Volcanol Geotherm Res. 2008;178(4):837-46.

Seevers MH. The narcotic properties of carbon dioxide. N Y State Med J. 1944;44: 597-602.

Sigurdsson H. Lethal gas bursts from Cameroon crater lakes. Eos. 1987;68:570-3.

Sigurdsson H, Devine JD, Tchoua FM, Presser TS, Pringle MKW, Evans WC. Origin of the lethal gas burst from Lake Monoun, Cameroon. J Volcanol Geotherm Res. 1987;31:1-16

Sorey ML, Evans WC, Kennedy BM, Farrar CD, Hainsworth LJ, Hausback B. Carbon dioxide and helium emissions from a reservoir of magmatic gas beneath Mammoth Mountain, California. J Geophys Res. 1998;103:15,303.

Stephenson R, Burr G, Kawamoto M, Hills B. Exposures to volcanic emissions from the Hawaiian Volcanoes: a NIOSH health hazard evaluation. Appl Occup Environ Hyg. 1991;6:408-10.

Strabo A. The Geography. Volume VI, Books XIII to XIV. In: Jones HL, editor. Loeb classical library, vol. 223. Cambridge, Massachusetts: Harvard University Press; 1924.

Stupfel M, Le Guern F. Are there biomedical criteria to assess an acute carbon dioxide intoxication by a volcanic emission? J Volcanol Geotherm Res. 1989; 39:247-64.

Tazieff H, Le Guern F, Carbonnelle J, Zettwoog P. Etude chimique des fluctuations des gaz eruptifs de volcan Erta 'Ale (Afar Ethiopia). C R Acad Sci Paris Series D. 1972;274:1003-6.

Thesiger W, Meynell M. On a collection of birds from Danakil, Abyssinia. Ibis. 1935;77(4):774-807.
Walsh M (2013). Gateway to Hades said to be uncovered by Italian archaeologists in southwestern Turkey: Is it hell on Earth? New York Daily News, 23 December 2015. http://www.nydailynews.com/news/world/gateway-hadesuncovered-turkey-archaeologists-article-1.1307747\#ixzz2QFYTutwC

Weber C (2015). Volcano Expedition International. Erta Ale and Danakil 2009. www.v-e-i.de. Accessed on 23 December 2015.

Weed WH. A deadly gas spring in the Yellowstone Park. Science. 1889;13(315): $130-2$.

Wright TJ, Ebinger C, Biggs J, Ayele A, Yirgu G, Keir D, et al. Magma-maintained rift segmentation at continental rupture in the 2005 Afar dyking episode. Nature. 2006:442:291-4.

Yirgu G. Recent volcanic eruptions in the Afar Rift: hazards in the making. In: Asrat A (Compiler), Abstracts, 24th Colloquium of African Geology (CAG24), 40 years of GSAf (1973-2013): Earth Science Solutions to African Development Challenges, 8-14 January, 2013. Addis Ababa, Ethiopia: Millennium Hall; 2013.

Zuskin E, Mustajbegovic J, Jelinic JD, Pucarin-Svetkovic J, Milosevic M. Effects of volcanic eruptions on environment and health. Arh Hig Rada Toksilol. 2007; 58(4):479-86

\section{Submit your manuscript to a SpringerOpen ${ }^{\circ}$ journal and benefit from:}

- Convenient online submission

- Rigorous peer review

- Immediate publication on acceptance

- Open access: articles freely available online

- High visibility within the field

- Retaining the copyright to your article

Submit your next manuscript at springeropen.com 